\title{
SOCIO-ECONOMIC FACTORS PREDISPOSING FARMERS' PRODUCE TO PILFERAGE IN IDAH LOCAL GOVERNMENT AREA OF KOGI STATE, NIGERIA
}

\author{
C.O. Ebojei ${ }^{1}$, F.O. Odekina ${ }^{2}$, V.O. Mosimabale $^{3}$, A. N. Abdullahi ${ }^{4}$
}

\begin{abstract}
A study was carried out on six communities in Idah Local Government Area of Kogi State to determine the socioeconomic factors predisposing farmers produce to pilferage. Simple Random Sample was used to select a total of one hundred and ten respondents from the villages. Primary data were collected from the respondents using a structured questionnaire. Descriptive statistics and regression model were used to achieve the objectives of the study. The results show that about 74\% of the sampled farmers were between the ages of 20-49 years, $33 \%$ were female while $67 \%$ were male. The result also revealed that measures adopted by farmers in the study area to curb pilferage include vigilance group, charms and amulets, building of fences round farm/storage structure etc. Multiple regression result run on the socioeconomic factors showed that household size, Farm size, Security measures and Attractive farm/crop variety were the factors that predisposes farmers produce to pilferage. The study recommends the need for community/village heads and elders of good repute to have a meeting with a view to strengthening social controls in their communities that will checkmate defiant behaviours like pilferage.
\end{abstract}

Key Words: Pilferage, Charms, Amulets, Predisposing, Poverty.

\section{INTRODUCTION}

Food security may have different meanings for different people. The International Conference on Nutrition (ICN) held in Rome in 1992, defined food security as "access by all people at all times to the food needed for a healthy life" (FOA/WHO, 1992). Essentially, in order to achieve food security, a country must achieve three basic aims. It must:

- Ensure adequacy of food supplies in terms of quantity, quality, and variety of food;

- Optimize stability in the flow of supplies;

- Secure sustainable access to available supplies by all who need them.
Adequate food availability at the national, regional, local and household levels, obtained through markets and other channels, is the cornerstone of nutritional well-being. At the household level, food security implies physical and economic access to foods that are adequate in terms of quantity, nutritional quality, safety and cultural acceptability to meet each person's needs. However, pilferage, which is the clever way of stealing, perpetuated through deliberate and fraudulent removal of a farmers produce by another person on a continuous basis with a view to making the farmer unsuspecting of the loss until the loss reaches an alarming extent has become frequent in Kogi State, Nigeria.

\footnotetext{
${ }^{1}$ Department of Extension Services, Agricultural Research Council of Nigeria, Abuja.

2Research Outreach Department, Rubber Research Institute of Nigeria, Benin, Edo State.

${ }^{3}$ Department of Agricultural Economics and Rural Sociology, Ahmadu Bello University,

Zaria, Kaduna State.

${ }^{4}$ Department of Agricultural Economics and Extension. Usmanu Danfodiyo University, Sokoto, Nigeria.
} 
One of the causes of poverty in the six villages of Ichekene, Ichala-Edeke, AllaOkweje, Aloko-Inah, Efulu and Ekwokata in Idah Local Government Area of Kogi State, Nigeria is pilferage on agricultural produce of farmers. Adefuye (1995) drew attention of scholars in Africa to the need for organized scientific inquiry on pilferage in Agriculture. Sequel to this, the National Research Network on Pilferage in Agriculture (NARNPA) was established on 1st May, 1995 with a view to finding out causes of and solution to pilferage in Agriculture (Anonguku, 2005).

Arable crop production in Nigeria has grown within the past few decades from an aggregate of backyard production into a thriving commercial production. The production of the crops has helped in no small measure as a source of staple food for most communities, as a good source of income when sold to brewing industries, bakery and confectionary industries and even fed to livestock. It is therefore hoped that hunger and poverty by most Nigerians would be a thing of the past. However, elimination of hunger and poverty still remains a mirage due to the activities of criminals who pilfer on these crops in an increasing manner. Adewodu (1991) noted that pilfering is a serious and formidable impediment to farming activities. It was cited that a single incident of pilfering might lead to withdrawal from farming activities.

This study was therefore premised on the basis of this realization, and was carried out to achieve the following objectives:

Describe the socioeconomic characteristics of arable crop farmers in the study area.

Ascertain the socioeconomic factors that pre-dispose farmers produce/crops to pilferage.
Identity measures adopted by farmers to reduce or curb pilferage of their produce in the study area.

\section{MATERIALS AND METHODS}

\section{Study area}

The study was conducted in Idah Local Government Area (LGA) of Kogi State. The choice of the area was essentially on the basis of the large potential for arable crops among the farmers. Kogi State is in the Southern Guinea Savanna ecological zone and lies between latitude $7^{\circ} \mathrm{N}$ and $8^{\circ}$ $31^{\prime} \mathrm{N}$ and longitude $5^{\circ} \mathrm{E}$ and $6^{\circ} 15^{\prime} \mathrm{E}$. The state has population figure of 3,040,043 (Ojo, 2008). The LGA has a typical savannah climate with distinct wet and dry season. The wet season falls between the month of April and October while the dry season falls between November and March. The annual rainfall ranges from $1100 \mathrm{~mm}$ to $1300 \mathrm{~mm}$. It has sandy lighthued grey/reddish in colour impervious soil. It has Guinea savanna vegetation with tall grasses and some trees. These are green in the rainy season with fresh leaves and grasses during the rainy season but the dry season shows charred trees and remains of burnt grasses.Farming accounts for $80 \%$ of the population of the area. The major crops grown are yam, cassava, maize, rice and tree crops such as oil palm, citrus, and cashew. Apart from crop farming, livestock such as goats, sheep and poultry are kept. Cropping pattern is mainly mixed cropping with few farmers practicing sole cropping.

\section{Sampling technique and data collection}

The total population of farmers in the study area was put at one thousand and ninety one (1091) by Kogi State Agricultural Development Project (KSADP). Ten percent of this population was selected using stratified random sampling technique to constitute the sample size. The break down is shown in Table 1. 
Table 01: Sample frame and sample size

\begin{tabular}{llll}
\hline S/No & Village & Population & Sample Size \\
\hline 1 & Allah Okweje & 78 & 8 \\
2 & Aloko-inah & 276 & 28 \\
3 & Efulu & 122 & 12 \\
4 & Ichekene & 122 & 12 \\
5 & Ekwokata & 197 & 20 \\
6 & Ichala-Edeke & 296 & 30 \\
\hline & Total & 1091 & 110 \\
\hline
\end{tabular}

Source: Field Survey Data, 2007

Primary data were collected from arable crop farmers based on 2006-2007 cropping activities. Information generated include farmers age, sex, income, level of education, farm size, storage system and location, available security measures on the farm to checkmate pilferage, nature of farm/variety of crop planted, sources of labour on the farm, perceived causes of pilferage, perceived sources of pilferage and effects of pilferage on them etc. Secondary data were also obtained from existing literatures relevant to the study.

\section{Model specification}

Descriptive statistic was used to analyze and summarize the data that were collected. This involves the use of measures of central tendency such as frequency distribution and percentages.

\section{The explicit form of multiple regression model specified in this study is as follows}

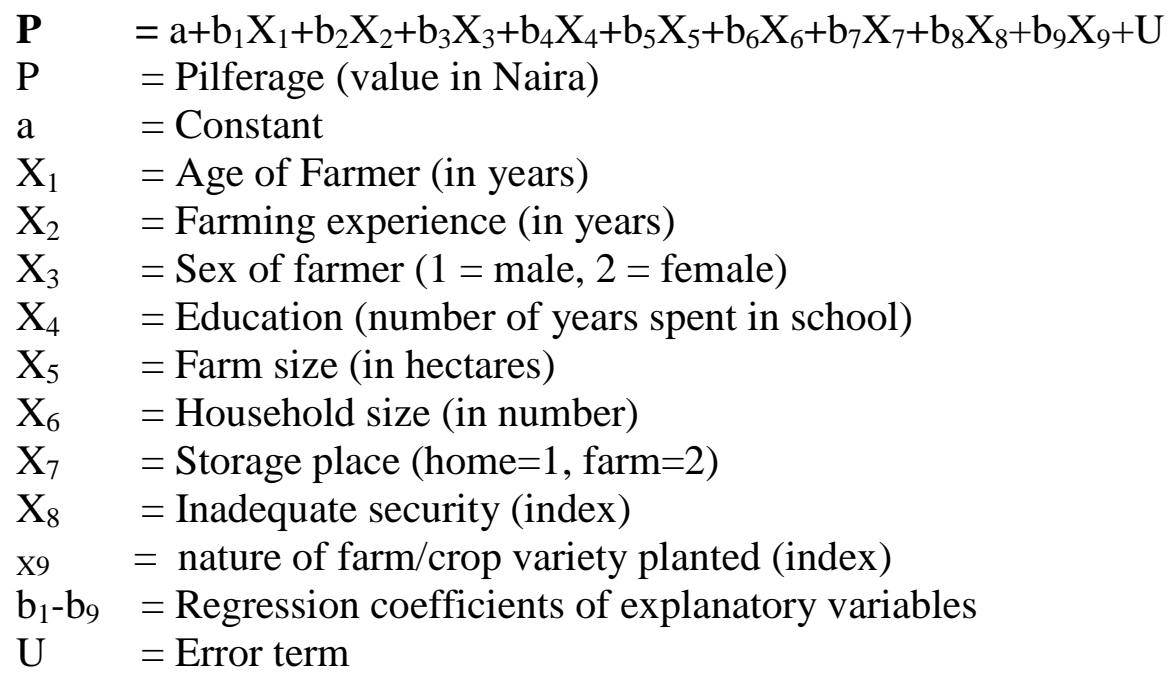

\section{RESULT AND DISCUSSION}

\section{Socioeconomic characteristics of sampled farmers}

Table 02 shows the socio-economic characteristics of arable crop farmers in the study area. About $74 \%$ of the sampled farmers were between the ages of 20-49 years. This shows that majority of the sampled farmers were middle age. It implies that they are still in their economic active age which could result in positive 
effect on production. Age classification is relevant to this study in that physical ability, productivity and agility depends on age and this will determine predisposition or susceptibility of farmers produce to pilferage.

Thirty six farmers representing about 33\% were female while majority of the farmers (seventy four in number) representing about $67 \%$ of respondents were male. This gender categorization was done based on household head. Majority of the respondents $(76 \%)$ had one form of education or the other. Twenty six respondents representing about $24 \%$ had no formal education. Forty three respondents representing 39\% had primary education. Education plays a major role in creating awareness among farmers and influences the adoption of strategies and techniques that can prevent or curb pilferage. It has been observed generally that formal education has a positive influence on the adoption of innovation.

Land is communally owned in the six villages under study. Nobody is allowed to have beyond one and half hectare. Land is allocated to farmers in three categories 0.5 ha, 1 ha and 1.5 ha. Fifty five farmers, representing $50 \%$ of the respondents had 0.5 hectares of farm land. Thirty nine farmers representing about $36 \%$ of the respondents had 1 hectares of farmland while only sixteen farmers representing about $15 \%$ of the respondents had 1.5 hectare of farmland.

About $58 \%$ of the respondents have been in farming for more than 5 years. Farming experience is used as a measure of management ability. The more experienced the farmer is, the more his ability to make better farm decision. This result shows that most of the farmers had experience, implying that such farmers are likely to make decisions that would prevent or curb pilferage and hence enhance their income.

Sixty eight farmers representing about $62 \%$ had a household size of between 6 10 persons. Household size is very important when pilferage is discussed. This is because pilferage is of two sources; External and Internal sources. Pilferage perpetuated by family members of the farmer constitute internal source while that perpetuated by outsiders constitute external source. Hence household size may determine the rate of internal pilferage.

About $71 \%$ of respondents store their produce at home. Thirty two farmers, representing about 29\% store their produce/harvest on the farm in entirety. Produce storage point was included in the study to ascertain whether pilferage was rampant at home or on the farm. Thirty nine farmers representing 35\% used hybrid variety of crops and kept their farms weedfree throughout. Thirty three of them representing 30\% used hybrid variety but did not keep their farms totally weed free throughout the gestation period. Twenty two respondents representing $20 \%$ used local variety but kept their farms totally weed free throughout the gestation period. However, sixteen respondents representing $15 \%$ used local variety and did not keep their farm weed free throughout the gestation period. The result shows that about $65 \%$ of the respondents had hybrid variety of crops grown on their farms and maintained a clean farm through weeding. These characteristics ordinarily attracts pilfers to the farm and this can be attested to in the regression analysis where attractiveness of the farm was significant. 
Table 02: Socioeconomic characteristics of arable crop farmers

\begin{tabular}{|c|c|c|}
\hline Characteristics & Frequency & Percentage \\
\hline \multicolumn{3}{|l|}{ Age (years) } \\
\hline $20-29$ & 11 & 10.00 \\
\hline $30-39$ & 24 & 21.82 \\
\hline $40-49$ & 46 & 41.82 \\
\hline $50-59$ & 23 & 20.91 \\
\hline$\geq 60$ & 06 & 05.45 \\
\hline Total & 110 & 100 \\
\hline \multicolumn{3}{|l|}{ Sex/Gender } \\
\hline Male & 74 & 67.27 \\
\hline Female & 36 & 32.73 \\
\hline Total & 110 & 100 \\
\hline \multicolumn{3}{|l|}{ Level of Education } \\
\hline No Formal Education & 26 & 23.64 \\
\hline Primary Education & 43 & 39.09 \\
\hline Secondary / Grade II & 28 & 25.45 \\
\hline Diploma / NCE & 09 & 08.18 \\
\hline HND / B Sc/ B.A. & 04 & 03.64 \\
\hline Total & 110 & 100 \\
\hline \multicolumn{3}{|l|}{ Farm Size (ha) } \\
\hline 0.50 & 55 & 50.00 \\
\hline 1.00 & 39 & 35.45 \\
\hline 1.50 & 16 & 14.50 \\
\hline Total & 110 & 100 \\
\hline \multicolumn{3}{|l|}{ Farming Experience (years) } \\
\hline $1-5$ & 46 & 41.82 \\
\hline $6-10$ & 26 & 23.64 \\
\hline $11-15$ & 11 & 10.00 \\
\hline $16-20$ & 11 & 10.00 \\
\hline $21-25$ & 08 & 07.27 \\
\hline$>25$ & 08 & 07.27 \\
\hline Total & 110 & 100 \\
\hline \multicolumn{3}{|l|}{ House hold Size } \\
\hline $1-5$ & 24 & 21.82 \\
\hline $6-10$ & 68 & 61.82 \\
\hline $11-20$ & 18 & 16.36 \\
\hline Total & 110 & 100 \\
\hline \multicolumn{3}{|l|}{ Storage Place } \\
\hline Home Storage & 78 & 71.00 \\
\hline Farm Storage & 32 & 29.00 \\
\hline Total & 110 & 100 \\
\hline \multicolumn{3}{|c|}{ Attractiveness of farms/crop varieties } \\
\hline Weeded throughout/hybrid variety & 39 & 35 \\
\hline Weeded partially/hybrid variety & 33 & 30 \\
\hline Weeded throughout/local variety & 22 & 20 \\
\hline Weeded partially/local variety & 16 & 15 \\
\hline Total & 110 & 100 \\
\hline
\end{tabular}

Source: Field Survey Data, 2007. 
Ascertaining socioeconomic factors predisposing farmers produce to pilferage Empirical results from socio-economic factors that predisposed farmers' produce/ crops to pilferage were obtained by means of multiple regression analysis. The linear function was estimated as:

\section{$\mathrm{P}=5.61-2.955 \mathrm{x}_{1}+0.247 \mathrm{x}_{2}-110 \mathrm{x}_{3}+$ $2.894 x_{4}+2.006 x_{5}+7.426 x_{6}+5.485 x_{7}+$ $0.702 x_{8}+2.002 x_{9}$}

The regression results shown in Table 03 indicate that about 71.5 percent of the variability in pilferage was accounted for by the explanatory variables in the model. The regression signs for farming experience, education, farm size, household size, storage place, security measures and attractive farm/crop variety show positive relationship with disposition or susceptibility to pilferage, while that of age of farmer and sex show negative relationship.

Household size is significant at 5\% level. This is because pilferage is of two dimensions - external and internal pilferage. While external pilferage is that perpetuated by outsiders, internal pilferage constitute those perpetuated by family members hence the more the household size the higher the susceptibility of the produce to internal pilferage even though large household may mount enough security against external pilferage.

Farm size, security measures and attractive farm/crop variety are significant predisposing factors to pilferage at $1 \%$ level because the greater the farm size, the more the harvest and the more the harvest, the less likely a farmer is able to keep an eye on his produce. So also the kind of security measures adopted by a farmer determines susceptibility of his produce to pilferage because when thieves are aware of a farmer having effective and solid security measures, they look elsewhere. Charms and amulets were discovered to be most effective in reducing and curbing pilferage in the study area. Finally farmers having hybrid variety of crops conspicuously displayed on their farms are prone to pilferage since thieves prefer the best especially in local setting where most farmers use local varieties.

Based on the above analysis, the socioeconomic factors of farmers which predispose the crops/produce to pilferage in the study area were determined to be farming inexperience, large household size, inadequate/inappropriate security measures and the use of attractive variety of crop in a clean farm. The F-value which measures the joint significance of all the explanatory variables in the model was 23.4 and it was significant at 1 percent level of probability.

\section{Measures taken by farmers to reduce or curb pilferage in the study}

As can be viewed from table 04, about $29 \%$ of the respondents rely heavily on vigilance/age grade. They stated that although vigilante and age grade mount security at nights to wage war against pilferage, they could not curb pilferage in entirety but only help in reducing the incidence to the barest minimum.

Thirty one farmers in the study area representing about $28 \%$ had no visible security measures on their farms. They were well aware of pilferage but they claimed there was nothing they could do but pray for divine intervention. Forty two farmers representing about $38 \%$ of the total number of respondents utilized various kinds of charms known as "ebo" to protect their produce from pilferage. While some see it as being effective, others opined that "ebo" is there to scare pilferers from their produce. Some Items used as"ebo" on farms and produce include; rag 
(usually red in colour), snail shell, maize husk, small gourd.

Only 5 farmers representing about $5 \%$ of the entire respondents had their farms fenced round. This figure is low because most of the farmers are peasant farmers with low income. Thus they don't have enough money to spend on fencing farmlands.

Table 03: Multiple regression results of socio-economic factors predisposing farmers produce to pilferage

\begin{tabular}{|c|c|c|c|c|}
\hline $\begin{array}{l}\text { Variables (Predisposing } \\
\text { factors to pilferage) }\end{array}$ & $\begin{array}{l}\text { Regression } \\
\text { coefficient }\end{array}$ & SE & T-value & $\begin{array}{ll}\text { Level of } \\
\text { significance }\end{array}$ \\
\hline Constant & 5.651 & 0.578 & 9.785 & 0.000 \\
\hline Age of farmers $\left(\mathrm{x}_{1}\right)$ & -2.955 & 0.013 & 236 & 0.814 \\
\hline Farming experience $\left(\mathrm{x}_{2}\right)$ & 0.247 & 0.147 & 1.677 & 0.098 \\
\hline $\operatorname{Sex}\left(x_{3}\right)$ & -110 & 0.149 & -733 & 0.466 \\
\hline Education $\left(\mathrm{x}_{4}\right)$ & 2.894 & 0.078 & 0.371 & 0.712 \\
\hline Farm size $\left(\mathrm{x}_{5}\right)$ & 2.006 & 0.308 & 6.504 & $0.000 *$ \\
\hline Household size $\left(\mathrm{x}_{6}\right)$ & 7.426 & 0.030 & 2.499 & $0.015 * *$ \\
\hline Storage place $\left(\mathrm{x}_{7}\right)$ & 5.485 & 0.078 & 0.701 & 0.483 \\
\hline Security measures $\left(\mathrm{x}_{8}\right)$ & 0.702 & 0.088 & 7.975 & $0.000 *$ \\
\hline Attractiveness of farm $\left(\mathrm{x}_{9}\right)$ & 2.002 & 0.304 & 6.304 & $0.000 *$ \\
\hline $\begin{array}{l}* \text { coefficient statistically sign } \\
* * \text { coefficient statistically sig } \\
\mathrm{R}^{2}=71.8 \% \\
\mathrm{R}^{-2}=71.5 \\
\mathrm{~F}=23.4\end{array}$ & $\begin{array}{l}\text { ant at } 1 \% \\
\text { cant at } 5 \%\end{array}$ & & & \\
\hline
\end{tabular}

Table 04: Measures Taken By Farmers to reduce or curb pilferage in the study area

\begin{tabular}{lll}
\hline Measure taken & Number of farmers & Percentage \\
\hline No measure & 31 & 28.18 \\
Vigilante/age grade & 32 & 29.09 \\
Charms/amulets & 42 & 38.18 \\
Fence & 05 & 04.54 \\
Total & 110 & 100 \\
\hline
\end{tabular}

\section{CONCLUSIONS}

Based on the findings of this study, it is concluded that pilferage is highly rampant among the six communities studied. Socioeconomic factors pre-disposing farmers produce to pilferage were found to include: large household size, large farm size, inappropriate/inadequate security measures and attractiveness of farm. Measures adopted by farmers to prevent pilferage in the study area include the use of fence, vigilance group and charms.

In view of the conclusion above, the following recommendations are proffered. 
There is need for community/village heads to organize meeting with a view to checkmate the activities of defiant members of the communities who are involved in pilferage. Farmers should also organize vigilance group in order to checkmate the activities of those who pilferer their crops.

The need for the government to extend its poverty alleviation programme to the rural youths is highly essential as the entire respondents implicated rural youths for pilferage.

\section{REFERENCES}

Adefuye B.O. (1995) Pilferage on Farms: An area of Scientific Inquiry in Agriculture. Proceedings of Pilferage on Farms. Nigeria Samfard Farm Foundation P. 7-9

Anonguku, I. (2005) Incidence of Livestock Pilferage in Benue State. Unpublished M.Sc. Thesis in Extension and Communications. University of Agriculture, Makurdi, Benue State, Nigeria. $73 \mathrm{Pp}$

Blake, R.I. and Mouton, J.S. (1964). The Managerial Grid. Texas: Gull Publishing S. (1964). Pp. 131-139.

Food and Agriculture Organization/World Health organization (1992) Agriculture Food Security and Nutrition in International Conference on Nutrition (ICN) Rome 1992.

Idisi, P.O. and Okoh, P.E. (2003). Economic Planning and Budgetary Allocation in Nigeria: A case for Agricultural Sector. Journal of Administration and Management. University of Abuja Publishers (2003) Pp 1-23.

Odekina, F. O. (2009) Assessment of Effects of Pilferage on Arable Crop Farmers in Idah Local Government Area of Kogi state, Nigeria. Unpublished M.Sc. Thesis in Extension, Department of Agricultural Economics and Rural Sociology, Ahmadu Bello University, Zaria Nigeria, $61 \mathrm{PP}$.

Ojo, H.I. (2008). Assessment of Factors Influencing Adoption of Cassava Production Technologies Among Women Farmers in Mopamuro Local Government Area, Kogi State. Unpublished M.Sc. Thesis, Department of Agricultural Economics and Rural Sociology, Ahmadu Bello University, Zaria.

World Bank, (2001): Annual Reports (1997, 1998, and 1999), Washington, D.C., USA. 